\title{
Studies of $\mathrm{Fe}(\mathrm{II}), \mathrm{Mn}(\mathrm{II}), \mathrm{Cr}(\mathrm{II}), \mathrm{Ni}(\mathrm{II}), \mathrm{Co}(\mathrm{II})$ and $\mathrm{Cu}$ (II) Complexes with Schiff Base Derived from 2-Amino-4,6-dimethylbenzothiazole and Pyridine-2- aldehyde
}

\author{
V.G. DESHPANDE and SEEMA I HABIB* \\ Department of Chemistry, G. M. Momin Women's College, Bhiwandi, Maharashtra, India \\ seemahabib12@gmail.com
}

Received 3 November 2016 / Accepted 21 December 2016

\begin{abstract}
As it is proved that the transition metal complexes have drug activities, hence we have synthesized heterocyclic Schiff bases. Six complexes of $\mathrm{Co}(\mathrm{II}), \mathrm{Ni}(\mathrm{II}), \mathrm{Fe}(\mathrm{III}), \mathrm{Mn}$ (II), $\mathrm{Cr}(\mathrm{II})$ and $\mathrm{Cu}$ (II) Schiff bases have been prepared. All ligands and its metal complexes the structures of the complexes have been proposed by analytical data, conductivity measurement, magnetic moment, IR, ${ }^{1} \mathrm{H}$ NMR spectra and thermal studies. Analytical data confirmed 1:2 (metal:ligand) stoichiometry and the spectral data suggest that all $\mathrm{Fe}(\mathrm{III}), \mathrm{Mn}(\mathrm{II}), \mathrm{Cr}(\mathrm{II}), \mathrm{Ni}(\mathrm{II})$ and $\mathrm{Co}(\mathrm{II})$ complexes have octahedral geometry where as the $\mathrm{Cu}(\mathrm{II})$ metal complex shows the square planar geometry. The molar conductance values of metal complexes suggest their non electrolytic nature. The IR spectral data reveals that the ligand behaves as bidentate with $\mathrm{ON}$ donor atoms sequence towards central metal ion. Antibacterial and antifungal activities of ligands and its metal complexes were performed in vitro against E.coli, S. typhi, S. aureus, B. subtilis and against various fungi like P.chrysogenum, A. niger, F. moniliformae, and A.Flavus. The complexes show more activity compare to the ligand.
\end{abstract}

Keywords: Substituted benzothiazole Schiff bases, Transition metal complexes, Spectral analysis, Antimicrobial activity

\section{Introduction}

Hetero donar groups like N, O containing metal complexes of Schiff bases gained importance for more than two decades because of their biological activities ${ }^{1-3}$, as antibacterial $^{4}$, antifungal ${ }^{5}$, antitumour ${ }^{6}$ and anti-inflammatory activities ${ }^{7}$.

Now a days it is a center of interest that is Schiff bases containing heterocyclic ring as they possesses biological, clinical, medicinal, analytical and pharmacological fields ${ }^{8-10}$. The activity of the bezothiazole Schiff bases enhances by combining with the metal ions. All these review encourages the study of the metal chelates of the substituted benzothiazole transition metal complexes. 
Following all these observations of studies and a part of our research we report here the synthesis and structural studies on the transition metal complexes of $\mathrm{Co}(\mathrm{II}), \mathrm{Ni}(\mathrm{II}), \mathrm{Fe}(\mathrm{III})$, $\mathrm{Mn}(\mathrm{II}), \mathrm{Cr}(\mathrm{II})$ and $\mathrm{Cu}(\mathrm{II})$ with Schiff base of benzothiazole $\left(\mathrm{L}_{3}\right)$

\section{Experimental}

All the melting points were determined in an open capillary tube and are uncorrected completion of the reaction was monitored by thin layer chromatography on precoated sheets of silica gel G. All the reagents used were chemically pure and are of AR grade.

\section{Synthesis of 2 -amino - 4, 6 dimethylbenzothiazole}

Synthesis of 2-amino-4, 6-dimethylbenzothiazole was carried out by the standard method. $0.1 \mathrm{M}$ 2,4-xylidine(2,4-dimethylaniline) and sodium thiocyanate $(0.2 \mathrm{M})$ in $100 \mathrm{~mL}$ glacial acetic acid were mixed together and reaction mixture was cooled to $0{ }^{\circ} \mathrm{C}$ temperature. $0.2 \mathrm{M}$ bromine in acetic acid $(25 \mathrm{~mL})$ was added to the above solution drop wise and the mixture was stirred till the complete addition of bromine maintaining temperature below $5{ }^{\circ} \mathrm{C}$ throughout addition. Stirring was kept continued maintaining temperature below $5^{\circ} \mathrm{C}$ for half an hour after addition of bromine is made. The solid thus obtained after complete addition of bromine was filtered on vacuum and then dissolved in hot water. The solution was then treated with very dilute alkali like $\mathrm{NaOH}$ for the separation of free amine. The free amine thus obtained was filtered, washed and dried and was recrystallized from ethanol. Observed melting point is 140 ${ }^{\circ} \mathrm{C}$, yield $80 \%$. It was tested for free $\mathrm{NH}_{2}$ group.

\section{Synthesis of Schiff Base ligand}

Equimolar ethanolic solution of the $\mathrm{L}_{3}$ (pyridine-2-aldehyde) and 2-amino-4,6dimethylbenzothiazole were refluxed for 4-5 hours on water-bath and the reaction mixture was poured on ice cold water and the separated solid was collected by filtration, washing and drying, recrystallized from ethanol (Scheme 1). Melting point was recorded.

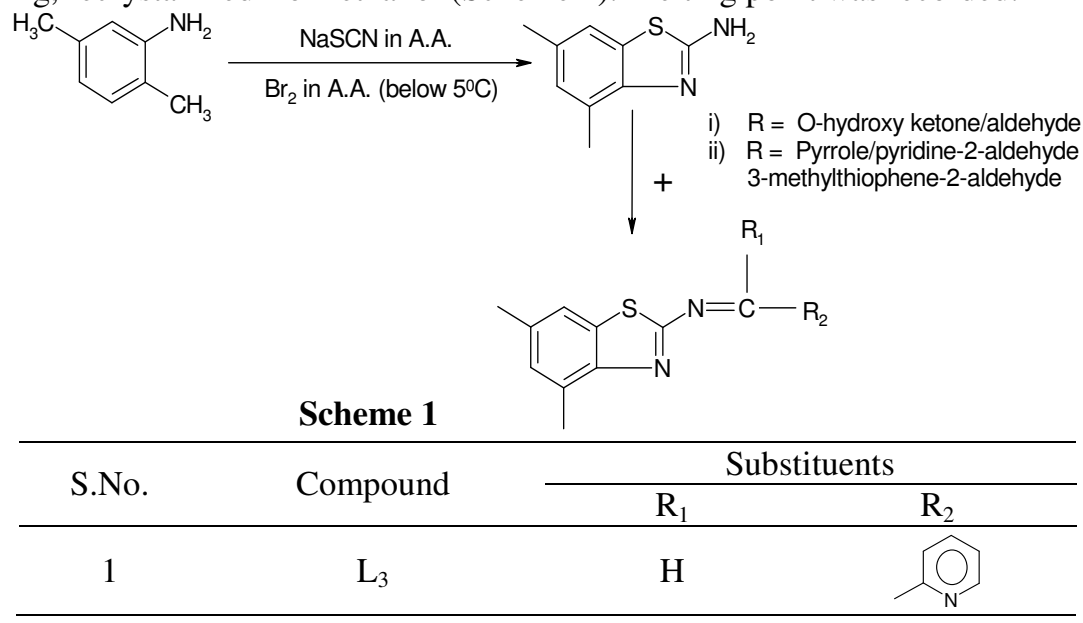

\section{Preparation of metal complexes}

For the synthesis of all $\mathrm{Cu}(\mathrm{II}), \mathrm{CoII}), \mathrm{Ni}(\mathrm{II}), \mathrm{Fe}(\mathrm{III}), \mathrm{Mn}$ (II) and $\mathrm{Cr}(\mathrm{II})$ complexes, the respective metal chlorides were used. Ethanolic solutions of Schiff base and respective metal chloride were refluxed in the stoichiometric ratio 1:2. After cooling, the solutions were treated with $10 \%$ alcoholic ammonia solution so as to raise the $\mathrm{pH}$ up to 5. Then the solid complexes separated in solution were filtered, washed to dry over fused $\mathrm{CaCl}_{2}$ in vacuum desiccators. 
Table 1. Analytical data of complexes

\begin{tabular}{|c|c|c|c|c|c|c|c|c|c|c|}
\hline \multirow[b]{2}{*}{$\begin{array}{l}\dot{z} \\
\dot{i}\end{array}$} & \multirow[b]{2}{*}{ Mol. Formula } & \multirow[b]{2}{*}{$\frac{\vec{s}}{\dot{0}}$} & \multirow[b]{2}{*}{ Colour } & \multirow[b]{2}{*}{ بن } & \multicolumn{4}{|c|}{ Elemental analysis, \% } & \multirow[b]{2}{*}{ 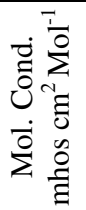 } & \multirow[b]{2}{*}{ 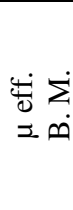 } \\
\hline & & & & & $\begin{array}{c}\mathrm{C} \\
(\mathrm{Cal}) \\
\text { Found }\end{array}$ & $\begin{array}{c}\mathrm{H} \\
(\mathrm{Cal}) \\
\text { Found }\end{array}$ & $\begin{array}{c}\mathrm{N} \\
(\mathrm{Cal}) \\
\text { found }\end{array}$ & 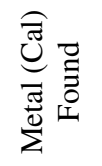 & & \\
\hline 1 & & 267 & & 0 & 6 & & & & & \\
\hline & $\begin{array}{c}\operatorname{Mn}\left(\mathrm{C}_{15} \mathrm{H}_{13} \mathrm{SN}_{3}\right)_{2} \\
2 \mathrm{H}_{2} \mathrm{O}\end{array}$ & 621 & & $>280$ & & & & $\begin{array}{c}(8.20) \\
8.68\end{array}$ & 124 & 5.88 \\
\hline & $\mathrm{Cu}\left(\mathrm{C}_{15} \mathrm{H}_{13} \mathrm{SN}_{3}\right)_{2}$ & 597 & $\begin{array}{l}\text { Parrot } \\
\text { Green }\end{array}$ & 274 & & $\begin{array}{c}(4.35) \\
4.56\end{array}$ & $\begin{array}{c}(14.07) \\
13.24\end{array}$ & $\begin{array}{c}(10.63) \\
9.47\end{array}$ & 130 & 1.81 \\
\hline & $\begin{array}{c}\mathrm{Co}\left(\mathrm{C}_{15} \mathrm{H}_{13} \mathrm{SN}_{3}\right)_{2} \\
2 \mathrm{H}_{2} \mathrm{O}\end{array}$ & 629 & $n$ & 272 & & $\begin{array}{c}(4.76) \\
4.34\end{array}$ & & $\begin{array}{c}(9.36) \\
8.73\end{array}$ & 118 & 5.16 \\
\hline & $\begin{array}{c}\mathrm{Ni}\left(\mathrm{C}_{15} \mathrm{H}_{13} \mathrm{SN}_{3}\right)_{2} \\
2 \mathrm{H}_{2} \mathrm{O}\end{array}$ & 628 & Brown & 254 & $\begin{array}{l}(57 . \\
56 .\end{array}$ & $\begin{array}{c}(4.77) \\
4.98\end{array}$ & $\begin{array}{c}(13.37) \\
12.67\end{array}$ & $\begin{array}{c}(9.34) \\
9.67\end{array}$ & 120 & 3.06 \\
\hline & $\begin{array}{c}\mathrm{Fe}\left(\mathrm{C}_{15} \mathrm{H}_{13} \mathrm{SN}_{3}\right)_{2} \\
2 \mathrm{H}_{2} \mathrm{O}\end{array}$ & 625 & Grey & 182 & $\begin{array}{c}(57.60) \\
56.34\end{array}$ & $\begin{array}{c}(4.80) \\
3.78\end{array}$ & $\begin{array}{c}(13.44) \\
13.68\end{array}$ & $\begin{array}{c}(8.93) \\
9.12\end{array}$ & 134 & \\
\hline & $\begin{array}{c}\mathrm{Cr}\left(\mathrm{C}_{15} \mathrm{H}_{13} \mathrm{SN}_{3}\right)_{2} \\
2 \mathrm{H}_{2} \mathrm{O}\end{array}$ & 622 & Green & $>280$ & $\begin{array}{c}(57.87) \\
56.32\end{array}$ & & & $\begin{array}{c}(8.35) \\
7.97\end{array}$ & 122 & \\
\hline
\end{tabular}

\section{Results and Discussion}

Magnetic susceptibility measurement of complexes

The magnetic susceptibility values of transition metal complexes were calculated by Guoy balance method results of the magnetic moment of $\mathrm{Co}$ (II) complexes are given in Table 1 . $\mathrm{Co}(\mathrm{II})$ complexes derived from ligand $\mathrm{L}_{3}$ show magnetic moment in the range 4.82-5.18 B.M at room temperature showing the Octahedral geometry ${ }^{11}$.

$\mathrm{Ni}(\mathrm{II})$ complexes of ligand $\mathrm{L}_{3}$ show magnetic moment values in the range of $2.72-3.18$ B.M at room temperature which is given in Table 1 showing octahedral geometry ${ }^{12,13}$. Magneticmoment of $\mathrm{Fe}(\mathrm{III})$ complexes derived from ligands $\mathrm{L}_{3}$ shows magnetic moment in the range 5.39-5.78 B.M at room temperature showing the octahedral geometry. $\mathrm{Mn}$ (II) complexes of the corresponding ligand shows magnetic moment values in the range of 5.92 B.M. at room temperature which is tabulated in table showing octahedral geometry. $\mathrm{Cr}$ (II) complexes showed magnetic moment in the range $4.90 \mathrm{~B} . \mathrm{M}$ at room temperature pointing towards the octahedral geometry

\section{Electronic spectral analysis}

The absorption spectra of transition metal complexes can be very well interpreted using ligand field theory (Table 2). The spectra of transition metal complexes have one or more weak absorption due to d-d transition. Electronic spectra of ligand exhibited maxima in the range of $230 \mathrm{~nm}$ to $420 \mathrm{~nm}$ respectively which can be assigned to $\mathrm{n} \rightarrow \Pi^{*}$ transitions of azomethine group. These bands showed blue shift in the complexes of $\mathrm{Cu}(\mathrm{II}), \mathrm{Co}(\mathrm{II}), \mathrm{Ni}(\mathrm{II})$, $\mathrm{Fe}(\mathrm{III}), \mathrm{Mn}(\mathrm{II})$ and $\mathrm{Cr}(\mathrm{II})$ respectively.

For $\mathrm{Cu}(\mathrm{II})$ complexes the electronic spectra showed bands in the range $22200 \mathrm{~cm}^{-1}$ to $41700 \mathrm{~cm}^{-1}$ i.e these spectral bands are observed near and above $3500 \mathrm{~cm}^{-1}$ can be assigned to charge transfer transitions. The bands at $34400 \mathrm{~cm}^{-1}$ to $37037 \mathrm{~cm}^{-1}$ are typically characteristic for square-planar geometry for $\mathrm{Cu}(\mathrm{II})$ complexes ${ }^{14-17}$. The electronic absorption spectra of $\mathrm{Co}$ (II) complexes displays the absorption bands in the range of 30,000 to $42,000 \mathrm{~cm}^{-1}$ which can be assigned due to charge transfer transitions ${ }^{18}$. The ligand field 
parameters like ligand splitting energy $(10 \mathrm{Dq}) \mathrm{cm}^{-1}$, ligand field stabilization energy (LFSE) in $\mathrm{K} . \mathrm{cal} / \mathrm{mole}$ and $v_{2} / v_{1}$ are consistent with the octahedral geometry ${ }^{19}$.

The octahedral geometry of $\mathrm{Ni}$ (II) complexes shows the absorption bands at 28,000 to $42,000 \mathrm{~cm}^{-1}$ which are due to ligand to metal charge transfer to $\mathrm{Ni}(\mathrm{II})$ complexes. The spectral features of Fe(III) ions in octahedral surroundings are in accordance with theoretical considerations. Fe(III) complexes showed absorption peaks in the range of 28,000 to $43,000 \mathrm{~cm}^{-1}$ which can be again assigned due to charge transfer transitions.

For $\mathrm{Mn}(\mathrm{II})$ complexes the electronic spectral bands are observed in the range of $29,000 \mathrm{~cm}^{-1}$ to $43,000 \mathrm{~cm}^{-1}$ which can be assigned due to charge transfer transitions, whereas for $\mathrm{Cr}$ (II) complexes the electronic spectral bands are observed in the range of $30,000 \mathrm{~cm}^{-1}$ to $42,000 \mathrm{~cm}^{-1}$ which can be assigned due to charge transfer transitions. The medium intensity bands in the range of $34500 \mathrm{~cm}^{-1}$ to $43500 \mathrm{~cm}^{-1}$ due to $\Pi$ to $\Pi *$ transitions in the ligands remained unchanged in the spectra of most of the complexes.

Table 2. Electronic spectral data of the complexes

\begin{tabular}{cccccc}
\hline Complex code & $\mu_{1} \mathrm{~cm}^{-1}$ & $\mu_{1} \mathrm{~cm}^{-1}$ & $\mu_{2 /} \mu_{1}$ & $\beta=\frac{B^{1}}{B}$ & $\begin{array}{c}\text { LFSE } \\
(\text { Kcal/mole })\end{array}$ \\
\hline $\mathrm{Mn}-\mathrm{L}_{3}$ & 37878 & 43290 & 1.14 & 0.547 & 107.95 \\
$\mathrm{Co}-\mathrm{L}_{3}$ & 29416 & 38753 & 1.13 & 0.906 & 83.8 \\
$\mathrm{Ni}-\mathrm{L}_{3}$ & 37735 & 43290 & 1.15 & 0.461 & 107.5 \\
$\mathrm{Fe}-\mathrm{L}_{3}$ & 37878 & 43478 & 1.14 & 0.480 & 107.95 \\
$\mathrm{Cr}-\mathrm{L}_{3}$ & 37735 & 43103 & 1.14 & 0.576 & 107.5 \\
\hline
\end{tabular}

\section{IR Spectroscopy}

In the complexes of ligand ${ }^{27}$ the characteristic band at $3143 \mathrm{~cm}^{-1}$ for 2-pyridyl nucleus shows considerable downward shift in the band value there by showing the pyridine nitrogen's involvement in the coordination. Thus the ligand $\mathrm{L}_{3}$ is coordinating through thiazole ring nitrogen and pyridine ring nitrogen ${ }^{20-22}$.

The bands at $825-840 \mathrm{~cm}^{-1}$ and $740-756 \mathrm{~cm}^{-1}$ in almost all metal complexes can be assigned due to C-S-C thiazole vibrations ${ }^{23,24}$. The appearance of non-ligand band at 555$600 \mathrm{~cm}^{-1}$ can be attributed to M-N band ${ }^{25-27}$ where as the non-ligand band at $462-491 \mathrm{~cm}^{-1}$ can be attributed to M-O band ${ }^{38}$. The appearance of these new bands of M-N and M-O vibrations supports the involvement of $\mathrm{N}$ and $\mathrm{O}$ atoms in complexation with metal ions.

The band in the region of $3400-3550 \mathrm{~cm}^{-1}$ for $\mathrm{Co}(\mathrm{II}), \mathrm{Ni}(\mathrm{II}), \mathrm{Fe}(\mathrm{III}), \mathrm{Mn}$ (II) andCr(II) complexes can be assigned for coordinated water molecules ${ }^{20,29}$. This was evidenced by the formation of new bonds in the range $1120-1180 \mathrm{~cm}^{-1}$ corresponding to $\delta(-\mathrm{OH})$ of the coordination water ${ }^{30}$ reinforcing the presence of two coordinated water molecules in the compound, which is well supported by the thermo analytical data of these complexes which show appreciable thermal stability. In case of $\mathrm{Cu}$ (II) complexes the band appears nearly in the same region but it is supported to be because of surface water (hydrated water $)^{29,31-34}$. Again the thermograms and thermo analytical data supports this very fact strongly.

\section{${ }^{1}$ H NMR Spectra}

${ }^{1} \mathrm{H}$ NMR spectra of the transition complexes were recorded, unfortunately, however due to the presence of a metal ion, proton resonance was not affected and one could observe only broad peaks indicating the formation of the complex. 


\section{ESR Spectroscopy}

It is observed from ESR spectrum $\mathrm{Cu}(\mathrm{II})$ complexes that there is a single line resulting in the interaction of unpaired electron present in $\mathrm{Cu}$ (II) nucleus. The Table 3 reveals that the ' $\mathrm{g}_{\mathrm{av}}$ ' values less than 2.3 which suggest the existence of sufficient covalent nature of metal ligand bond. Also the $\mathrm{G}$ values less than 4 indicate that the $\mathrm{Cu}(\mathrm{II})$ complexes are strong field ligands. $\left[\mathrm{Cu}\left(\mathrm{L}_{3}\right)_{2}\right]$ complex shows anisotropy.

The ESR spectrum of $\mathrm{Mn}(\mathrm{II})$ complexes of ligands $\left[\mathrm{Mn}\left(\mathrm{L}_{3}\right)_{2}\right]$, shows single line resulting in the interaction of unpaired electron present in $\mathrm{Mn}$ (II) nucleus. Table 3 reveals that the $g_{a v}$ values are less than 2.3 which suggest the existence of sufficient covalent nature of metal ligand bond. Also the ' $G$ ' values less than 4 indicates that the $\mathrm{Mn}$ (II) complexes are strong field ligands. All the complexes show anisotropy.

The hyperfine splitting in positive amplitude and negative amplitude at respective magnetic field for each spectrum gave rise to two ' $\mathrm{g}$ ' values which are less than 2.3 suggests the covalent nature of complexes ${ }^{35}$.

Table 3. ESR spectral values of $\mathrm{Cu}(\mathrm{II})$ and $\mathrm{Mn}(\mathrm{II})$ complexes

\begin{tabular}{cccccc}
\hline Complex code & $g_{I I}$ & $g_{\wedge}$ & $g_{a v}$ & $\begin{array}{c}\text { G Axial symmetry } \\
\text { parameter }\end{array}$ & $\begin{array}{c}m_{\text {eff }} \text { BM from } \\
\text { Gouy Balance }\end{array}$ \\
\hline $\mathrm{Cu}\left(\mathrm{L}_{3}\right)_{2}$ & 1.870 & 1.821 & 1.837 & 0.72 & 1.74 \\
$\mathrm{Mn}\left(\mathrm{L}_{3}\right)_{2}$ & 1.669 & 1.747 & 1.747 & 0.765 & 5.88 \\
\hline
\end{tabular}

\section{$X$-Ray crystallography}

X-ray diffractograms of the metal complexes under investigation show good intense peaks indicating high crystallinity. The results obtained from computational data gave lattice parameter values as Lattice parameter values as $\mathrm{a}=\mathrm{b} \neq \mathrm{c}$ and $\alpha=\beta=\gamma$ which suggest tetragonal crystal structure of $\mathrm{P}$ type lattice for copper complex of ligand $\mathrm{L}_{4}$ and cobalt complex of ligand $\mathrm{L}_{3}$.

Lattice parameter values as $\mathrm{a} \neq \mathrm{b} \neq \mathrm{c}$ and $\alpha=\gamma \neq \beta$ which suggest monoclinic crystal structure of $\mathrm{P}$ type lattice for copper complex of ligand $\mathrm{L}_{3}$ and cromium complex of ligand.

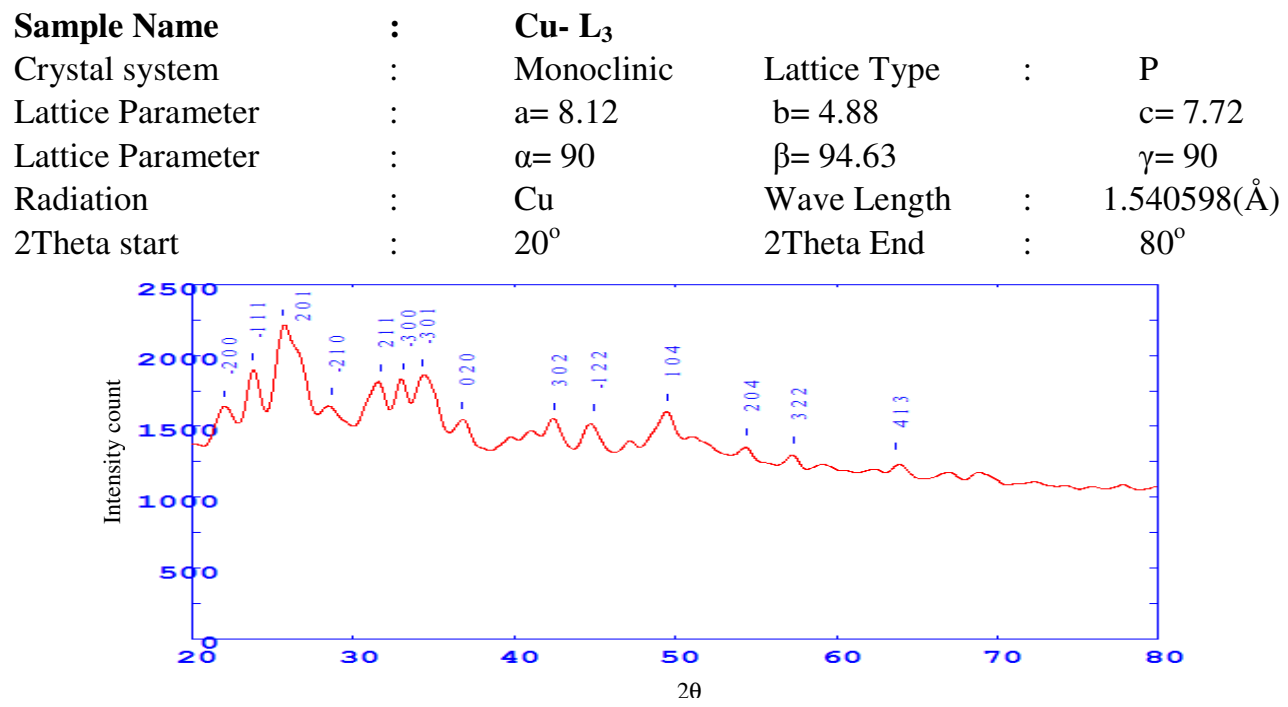

Figure 1. XRD of Copper complex 


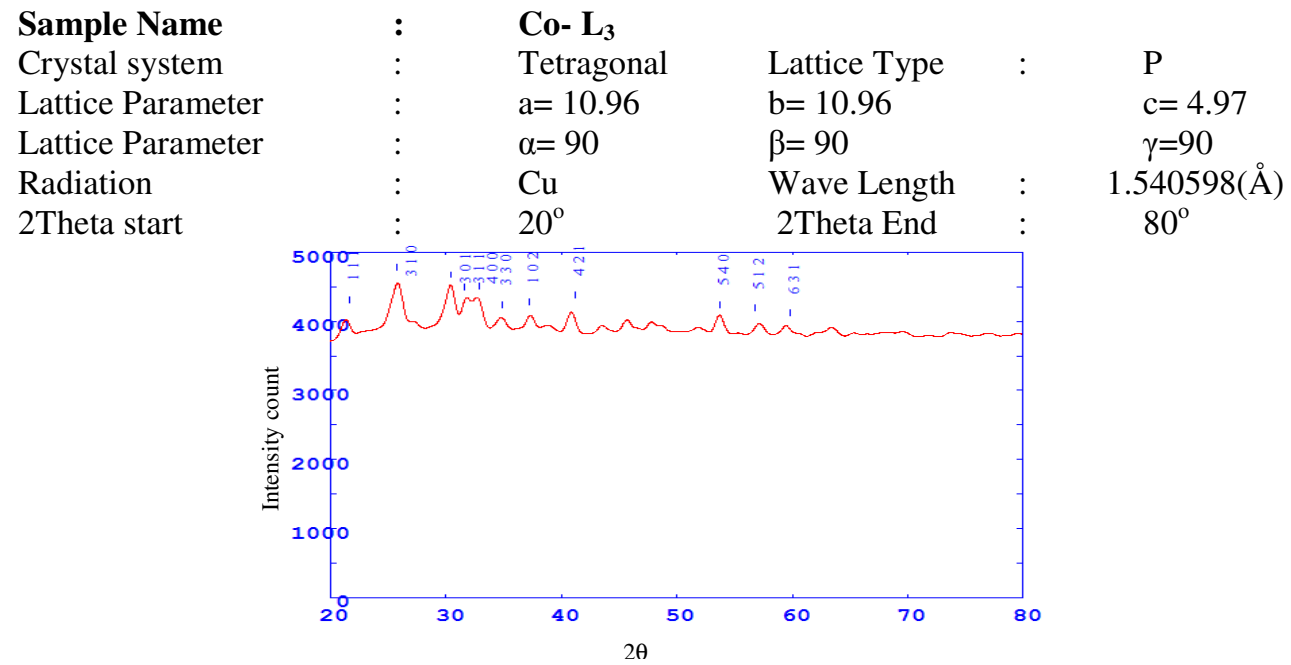

Sample Name

Crystal system

Lattice Parameter

Lattice Parameter

Radiation

2Theta start

Figure 2. XRD of Cobalt complex

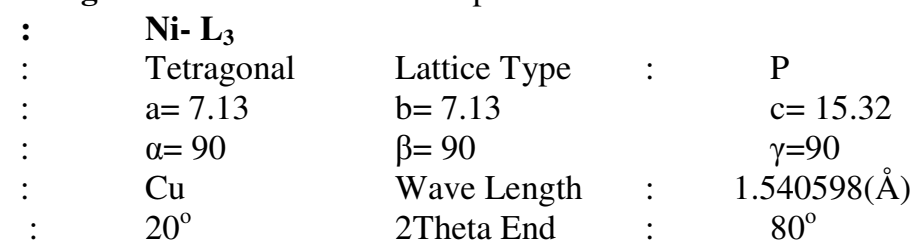

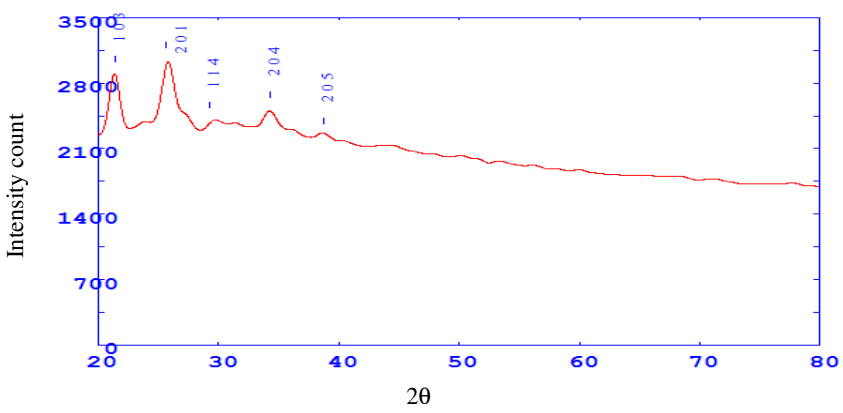

Figure 3. XRD of Nickel complex

From all above data of analysis the general structure of the complexes is

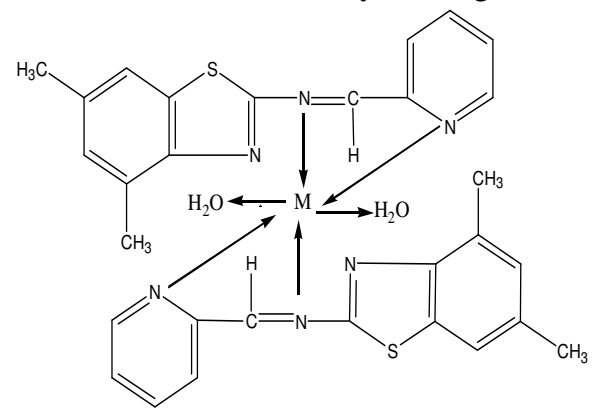

Figure 4. Structure of Complexes (Where $\mathbf{M}=\mathrm{Co}(\mathrm{II}), \mathrm{Fe}(\mathrm{II}), \mathrm{Mn}(\mathrm{II}), \mathrm{Ni}(\mathrm{II})$ and $\mathrm{Cr}(\mathrm{II})$ )

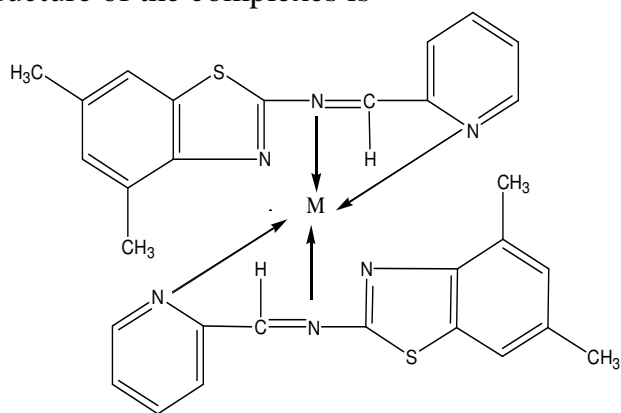

Figure 5. Structure of Complex (Where $\mathbf{M}=$ $\mathrm{Cu}(\mathrm{II}))$ 


\section{Antibacterial activity}

The antibacterial activity was measured by agar cup method. Nutrient agar (Himedia) was prepared and sterilized at 15 Psi for 15 minutes in the autoclave. It was allowed to cool below $45{ }^{\circ} \mathrm{C}$ and seeded with turbid suspension of test bacteria separately, prepared from ${ }^{24}$ hours old slant cultures. 3\% Inocula were used every time. The bacterial cultures selected were, two gram negative cultures viz. Escherichia coli, salmonella typhi and two Gram positive cultures viz. Staphylococcus aureus, Bacillus subtilis. This seeded preparation was then poured in sterile petri plate under aseptic condition and allowed it to solidify cups of $10 \mathrm{~mm}$ diameter were borered in the agar plate with sterile cork borer. $100 \mu \mathrm{L}$ of compound solution prepared in the cup under aspectic condition with the help of micropipette $100 \mu \mathrm{L}$ of DMSO was also placed in one of the cup as blank (negative control). A standard antibiotic disk impregnated with 10 units of penicillin was also placed on the seeded nutrient agar surface as standard reference antibiotic (positive control).

The plates were kept in refrigerator for 15 minutes to allow diffusion of the compound from agar cup into the medium. Then the plates were shifted to incubator at $37{ }^{\circ} \mathrm{C}$ and incubated for $24 \mathrm{~h}$. After incubation plates were observed for the zone of inhibition of bacterial growth around the agar cup. Results were recorded by measuring the zone of inhibition in millimeter (mm) using zone reader. Antibacterial Activity of the synthesized metal complexes is given in Table 4.

\section{Antifungal activity}

Antifungal activity was performed by poison plate method. The medium used was Potato Dextrose Agar (Himedia). The medium was prepared and sterilized at $10 \mathrm{Psi}$ in autoclave for 15 minutes. Then the compound to be tested is added to the sterile medium in aspetic condition so as to get final concentration as $1 \%$. Gresiofulvin was prepared as standard reference plate (positive control) Aspergilus niger, penicillium chrysogenum, Fusarium moneliforme, Aspergillus flavus were selected as test fungal cultures.

They were allowed to grow on slant for 48 hours so as to get profuse sporulation. $5 \mathrm{~mL}$ of 1:100 aqueous solution of Tween 80 was added to the slant and spores were scraped with the help of nicrome wire loop to form suspension.

The fungal suspension was spot inoculated on the plate's prepared using compound with the help of nicrome wire loop. The plates were incubated at room temperature for 48 hours. After incubation plates were observed for the growth of inoculated fungi. Results were recorded as growth of fungi (no antifungal activity) reduced growth of fungi (moderate antifungal activity) and no growth of inoculated fungi (antifungal activity). Antifungal Activity of the synthesized metal complexes is given in Table 5.

Table 4. Antibacterial activity of ligands and complexes

\begin{tabular}{cccccc}
\hline \multirow{2}{*}{ S.No. } & \multirow{2}{*}{ Compound } & \multicolumn{4}{c}{ Zone of inhibition in mm } \\
\cline { 3 - 6 } & & E.coli & S. Typhi & S. Aureus & B. Subtilis \\
\hline 1 & $\mathrm{~L}_{3}$ & $-\mathrm{ve}$ & 19 & 22 & 22 \\
2 & $\mathrm{Cu}-\mathrm{L}_{3}$ & 28 & 24 & 31 & 37 \\
3 & $\mathrm{Co}-\mathrm{L}_{3}$ & 18 & 20 & 28 & 39 \\
4 & $\mathrm{Ni}-\mathrm{L}_{3}$ & $-\mathrm{ve}$ & 23 & 28 & 37 \\
5 & $\mathrm{Fe}-\mathrm{L}_{3}$ & 22 & 23 & 27 & 23 \\
6 & $\mathrm{Mn}-\mathrm{L}_{3}$ & 18 & 17 & 31 & 30 \\
7 & $\mathrm{Cr}-\mathrm{L}_{3}$ & 18 & 16 & 18 & 15 \\
8 & DMSO & $-\mathrm{ve}$ & $-\mathrm{ve}$ & $-\mathrm{ve}$ & $-\mathrm{ve}$ \\
9 & Penicillin & 13 & 18 & 36 & 18 \\
\hline
\end{tabular}


Table 5. Antifungal activity of ligand and complexes

\begin{tabular}{|c|c|c|c|c|c|}
\hline \multirow[b]{2}{*}{$\begin{array}{l}\dot{z}_{i} \\
\text { is }\end{array}$} & \multirow[b]{2}{*}{ Compound } & \multicolumn{4}{|c|}{ Zone of inhibition in $\mathrm{mm}$} \\
\hline & & $\begin{array}{l}\text { Aspergillus } \\
\text { niger }\end{array}$ & $\begin{array}{l}\text { Penicillium } \\
\text { chrysogenum }\end{array}$ & Fusariummoneliforme & $\begin{array}{l}\text { Aspergillus } \\
\text { flavus }\end{array}$ \\
\hline 1 & $\mathrm{~L}_{3}$ & -ve & -ve & -ve & -ve \\
\hline 2 & $\mathrm{Cu}-\mathrm{L}_{3}$ & -ve & -ve & -ve & -ve \\
\hline 3 & $\mathrm{Co}-\mathrm{L}_{3}$ & -ve & -ve & -ve & $+\mathrm{ve}$ \\
\hline 4 & $\mathrm{Ni}-\mathrm{L}_{3}$ & -ve & $-\mathrm{ve}$ & -ve & -ve \\
\hline 5 & $\mathrm{Fe}-\mathrm{L}_{3}$ & -ve & -ve & -ve & -ve \\
\hline 6 & $\mathrm{Mn}-\mathrm{L}_{3}$ & -ve & $-\mathrm{ve}$ & -ve & -ve \\
\hline 7 & $\mathrm{Cr}-\mathrm{L}_{3}$ & -ve & -ve & -ve & -ve \\
\hline 8 & $\begin{array}{l}\text { +ve control } \\
\quad \text { (blank) }\end{array}$ & $+\mathrm{ve}$ & $+v e$ & $+\mathrm{ve}$ & $+\mathrm{ve}$ \\
\hline 9 & (Griseofulvin) & -ve & $-\mathrm{ve}$ & $-v e$ & -ve \\
\hline
\end{tabular}

\section{Conclusion}

The $\mathrm{Cu}(\mathrm{II}), \mathrm{Ni}(\mathrm{II}), \mathrm{Mn}(\mathrm{II}), \mathrm{Fe}(\mathrm{III}), \mathrm{Cr}(\mathrm{II})$ and $\mathrm{Co}(\mathrm{II})$ complexes are coloured, insoluble in most of the organic solvent but soluble in DMF and DMSO. The stoichiometry of the metal complexes obtained has been found to be 1:2. The infrared spectral data indicate that all the ligands act as mononegative bidentate species towards all the complexes. All the synthesized metal complexes gave satisfactory spectral and analytical data. The screening of antimicrobial data revealed that the all complexes show good antimicrobial activity.

\section{Acknowledgement}

The authors are thankful to Principal, Yeshwant Mahavidyalaya, Nanded for providing laboratory facilities and also to the Director, IICT, Hyderabad for providing the instrumentation facilities.

\section{References}

1. Israa A Hassan, Res J Chem Sci., 2013, 3(12), 50-53.

2. Buttrus H Nabeel and Saeed T, Res J Chem Sci., 2012, 2(6), 43-49.

3. You Z L and Zhu H L, Zeitschrift fur Anorganische undAllgemeine Chemie, 2004, 630(15), 2754-2760; DOI:10.1002/zaac.200400270

4. Kabeer A S, Baseer M A and Mote N A, Asian J Chem., 2001, 13(2), 496-500; DOI:10.1002/zaac.200400270

5. Rajasekar K, Ramachandramoorthy $\mathrm{T}$ and Balasubramaniyan S, Res J Chem Sci., 2013, 3(3), 48-51.

6. Desai S B, Desai P B and Desai K R, Hetrocycl Commun., 2001, 7(1), 83-90; DOI:10.1515/HC.2001.7.1.83

7. Zahid H C, Mohammad S I, Hummara S I, Claudiu T S, J Enzyme Inhibition Med Chem., 2002, 17(2), 87-91; DOI:10.1080/14756360290030734

8. Sindhukumarn B, Raijuulal G and Mohanan K, Synthe React Inorg Metal Org NanoMetal Chem., 2009, 39(1), 24-30.

9. Thankamony M and Mohanan K, Indian J Chem A, 2007, 46, 247-251.

10. Raman N, Dhaveethu Raja J and Sakthivel A, J Chem Sci., 2007, 119(4), 303-310; DOI:10.1007/s12039-007-0041-5 
11. More P G and Bhalwankar R B, J Indian Chem Soc., 2006, 83, 113-115.

12. Sharma P K, Sen A.K and Dubey S N, Indian J Chem., 1994, 33-A, 1031-1033.

13. Khulbe R C, Bhoon Y K and Singh R P, J Indian Chem Soc., 1981,58, 840-843.

14. Raman N, Antonysamy K, Chinnathangavel T and Kadarkaraithangam J, Trans Metal Chem., 2003, 28(1), 29-36; DOI:10.1023/A:1022544126607

15. Mokhles M Abd-Elzaher, J Chinese Chem Soc., 2001, 48(42), 153-158; DOI:10.1002/jccs.200100027

16. El Tabletal A S, Polish J Chem., 1999, 73(2), 245-254.

17. Shahazadi S, Ali S, Jabeen S and Khan A N, Russian J Coord Chem., 2008, 34(1), 38-43; DOI:10.1134/S1070328408010077

18. Sindhwani S K, Dutt Y and Singh R P, Indian J Chem., 1974, 12, 110.

19. Lutefullati, Ahmed Umar, Mohd Muzibur Rhhman and Yoon Beng Hahn, Turk $J$ Chem., 2007, 31, 179-189.

20. Mehta B H and Sampat N M, Asian J Chem., 1996, 8(2), 261-264.

21. Nakamoto K, Carthy P N, Ruby M C A and Martell A E, J Amer Chem Soc., 1961, 83(5), 1060-1063; DOI:10.1021/ja01466a012

22. Boghai Lachnizadajene, Syn Reac Inorg Metal Org Chem., 2000, 30(8), 1535-1540.

23. Colthup N B, Daly L N and Wiberley S E, Intro To IR and Raman Spectroscopy $2^{\text {nd }}$ Ed Academic Press, N.Y., 1975, 262, 270, 272, 430.

24. Morad V M, EL Ajaily and Ben Gweirf M M S, J Sci Appli., 2007, 1, 72-78.

25. Ramrao N, Rao V P, JayageRaju V J and Ganorkar M C, Ind J Chem., 1985, 24(4), 877.

26. (a) Rao N R and Ganorkar M C, Indian J Chem., 1988, 27(A)(52), 160; (b) Rao N R, Venkateshwar P R, Reddy G V and Ganorkar M C, Indian J Chem., 1987, 26A(10), 887.

27. Mane P S, Shirodkar S G and Chondekar T K, Indian J Chem., 2001, 40A(10), 11141117.

28. Venkateshwar Rao P, Ashwini K and Kaneeze Fatima, Asian J Chem., 2006, 18(1), 469-474.

29. Saha D K, Padhye S, Sinn S and Newton E, Indian J Chem., 2002, 41A, 279-283.

30. Khalil S M E, Mashaly M M and Emara A A, Synthesis React Inorg Metal-Organic Chem., 1995, 25(8), 1373-1389.

31. Mehta B H and Sampat, Asian J Chem., 1996, 8(2), 61.

32. Kanango P K, Sankhala N K and Mehta R K, JICS, 1986, 63(3), 335.

33. Natarajan P and Adamson A W, JICS, 1977, 54, 25.

34. Mathur K G and Praveen Mathur, JICS, 1981, 60, 107.

35. Maskar P T, Patil R M and Shaikh M M, Asian J Chem., 2007, 19(6), 4563-4574. 